\title{
$\boldsymbol{E}$

2013, Vol. 1, No. 1

\section{Editorial: Global Opportunities and Local Businesses}

It is our great pleasure to inaugurate our new journal 'Entrepreneurial Business and Economics Review' (EBER), which is a multi-disciplinary and multi-contextual journal, dedicated to serve as a broad and unified platform for revealing and spreading economics and management research focused on entrepreneurship, individual entrepreneurs as well as particular entrepreneurial aspects of business. We aim to focus on both entrepreneurial business as well as entrepreneurial economics.

For the first 2-3 years of our activity, we decided to use a double recognition. During this time, each issue will focus on a selected topic, forming a monograph with the ISBN number (the articles will be considered as book chapters). Parallel to that, we will consequently search for our own place on the publishing market and build our image as a journal dedicated to entrepreneurship. We will continue using the ISSN number for periodics. We do look forward to reaching international readers and gaining our own position among other journals through continuous efforts, commitment and dedication.

The theme of the first issue is very multi-disciplinary. It links economics with management by exploring global opportunities through particular local businesses. The European Union, as all of Europe, is now facing grand global challenges that primarily relate to economic issues. As stipulated by $\mathrm{H}$. Sirkin, J. Hemerling and A. Bhattacharya in their world-famous book: Globality: Competing with Everyone from Everywhere for Everything, in the resent future the European, American and Japanese firms will compete not only with each, other but increasingly with very competitive Chinese, Indian, South American, and even African firms, which currently may seem farfetched (Kotler \& Caslione, 2009, p. 29). We believe it is extremely important to recognise global opportunities, which have resulted from globalisation, internationalisation and Europeanisation processes (Wach, 2012, pp. 137-150 and 298-299).

The issue consists of 6 papers revealing how local businesses can take opportunity of global opportunities. These papers are related to the European dimension of international business, taking four Visegrad countries into special consideration.

Liwiusz Wojciechowski, a PhD student of the Faculty of Management of the Cracow University of Economics (Poland), in his article The Determinants of FDI Flows from the EU-15 to the Visegrad Group Countries - A Panel Gravity Model Approach analyses the inflows of foreign direct investment in four countries of our region namely the Czech Republic, Hungary, Poland and Slovakia. The article presents research results based on the original gravity model.

Judyta Lubacha-Sember, a PhD student of the Faculty of Economics and International Relations of the Cracow University of Economics (Poland), in her article High-Tech Export from the V4 Countries: Structure and Factors, discusses the impact of 
intellectual capital assents on the structure of high-tech export in Visegrad countries as well as its factors.

Robert K. Gruenwald, a PhD student of the Inter-Faculty PhD Study Programme of the Cracow University of Economics (Poland), in his article Entrepreneurship Challenges in High-Growth Companies and Consequences for SME Policy, presents the various research results on success factors of high-growth companies and presents relevant implications and recommendations for SME policy.

Remigiusz Lewandowski and Grażyna Rafalska, from the Polish Security Printing Works based in Warsaw (Poland), in their article The Internationalization Process - $A$ Case Study of PWPW S.A., expose the characteristics and peculiarities of the internationalisation process taking place in the company PWPW S.A.

Jana Gálová, from the Faculty of Economics and Management of the Slovak University of Agriculture in Nitra (Slovakia), in her article Opportunities for Doing Business with Countries Neighbouring V4 - The Case of Ukraine, discusses the possibilities that eastern partnership offers for European businesses and tries to give some recommendations for regional entrepreneurs based on the research survey and field experiences.

Mariusz Omelańczuk, a PhD student of the Warsaw School of Economics (Poland), in his article Export Platform FDI as a Concept for Growth - Selected Global Experiences, discusses a relatively new concept of export-platform FDI (EPFDI) by referring to American, Asian and European experiences taking Poland into special consideration.

I hope you will find these works of much interest and I invite you to participate in our academic conversation, for which we have set a stage in the form of our new journal.

Krzysztof Wach

Editor-in-Chief

\section{REFERENCES}

Kotler, Ph. \& Caslione, J.A., 2009, Chaotics. The Business of Managing and Marketing in the Age of Turbulence, New York NY: AMACOM Inc.

Sirkin, H., Hemerling, J. \& Bhattacharya A., 2008, Globality: Competing with Everyone from Everywhere for Everything, New York NY: The Boston Consulting Group Inc.

Wach, K., 2012, Europeizacja małych i średnich przedsiębiorstw: rozwój przez umiędzynarodowienie, Warszawa: Wydawnictwo Naukowe PWN. 